\title{
Ryanodine is a Positive Modulator of Acetylcholine Receptor Gating in Cochlear Hair Cells
}

\author{
Javier Zorrilla de San Martín, ${ }^{1}$ Jimena Ballestero, ${ }^{1}$ Eleonora Katz, ${ }^{1,2}$ A. Belén Elgoyhen, ${ }^{1,3}$
} ANd Paul A. Fuchs ${ }^{4}$

\author{
${ }^{1}$ Instituto de Investigaciones en Ingeniería Genética y Biología Molecular, Consejo Nacional de Investigaciones Científicas y \\ Técnicas, Buenos Aires, 1428, Argentina \\ ${ }^{2}$ Departamento de Fisiología, Biología Molecular y Celular, FCEyN, Universidad de Buenos Aires, Buenos Aires, 1428, \\ Argentina \\ ${ }^{3}$ Tercera Cátedra de Farmacología, Facultad de Medicina, Universidad de Buenos Aires, Buenos Aires, 1121, Argentina \\ ${ }^{4}$ Department of Otolaryngology, Head and Neck Surgery, and Center for Hearing and Balance, The Johns Hopkins University \\ School of Medicine, 720 Rutland Avenue, Baltimore, MD 21205-2195, USA \\ ${ }^{5}$ Oto-HNS Research, Johns Hopkins University School of Medicine, 818 Ross Building, 720 Rutland Avenue, Baltimore, MD \\ 21205-2195, USA
}

Received: 17 May 2007; Accepted: 22 June 2007; Online publication: 24 July 2007

\begin{abstract}
The efferent synaptic specialization of hair cells includes a near-membrane synaptic cistern, whose presence suggests a role for internal calcium stores in cholinergic inhibition. Calcium release channels from internal stores include 'ryanodine receptors', whose participation is usually demonstrated by sensitivity to the eponymous plant alkaloid, ryanodine. However, use of this and other store-active compounds on hair cells could be confounded by the unusual pharmacology of the $\alpha 9 \alpha 10$-containing hair cell nicotinic cholinergic receptor (nAChR), which has been shown to be antagonized by a broad spectrum of compounds. Surprisingly, we found that ryanodine, rather than antagonizing, is a positive modulator of the $\alpha 9 \alpha 10$ nAChR expressed in Xenopus oocytes, the first such compound to be found. The effect of ryanodine was to increase the apparent affinity and efficacy for acetylcholine (ACh). Correspondingly, ACh-evoked currents through the isolated cholinergic receptors
\end{abstract}

Correspondence to: Paul A. Fuchs · Oto-HNS Research · Johns Hopkins University School of Medicine 818 Ross Building, 720 Rutland Avenue, Baltimore, MD 21205-2195, USA. Telephone: +1410-9556311; fax: +1-410-6144748; email: pfuchs@jhmi.edu of inner hair cells in excised mouse cochleas were approximately doubled by $200 \mu \mathrm{M}$ ryanodine, a concentration that inhibits gating of the ryanodine receptor itself. This unusual positive modulation was not unique to the mammalian receptor. The response to ACh of chicken 'short' hair cells likewise was enhanced in the presence of $100 \mu \mathrm{M}$ ryanodine. This facilitatory effect on current through the AChR could enhance brief $(\sim 1 \mathrm{~s})$ activation of associated calciumdependent $\mathrm{K}^{+}(\mathrm{SK})$ channels in both chicken short hair cells and rat outer hair cells. This novel effect of ryanodine provides new opportunities for the design of compounds that potentiate $\alpha 9 \alpha 10$-mediated responses and for potential inner ear therapeutics based on this interaction.

Keywords: ryanodine, nicotinic receptors, $\alpha 9 \alpha 10$ receptors, ion channels, acetylcholine, efferent system

\section{INTRODUCTION}

Ryanodine is a plant alkaloid that affects calciumrelease channels, 'ryanodine receptors' (RyR) present in internal calcium stores identified in a variety of cell systems (Coronado et al. 1994; Rousseau et al. 1987) including hair cells of the cochlea (Lioudyno 
et al. 2004). Although an agonist at low concentrations, ryanodine acts as an antagonist of the calciumrelease channels at higher concentrations. In isolated organelles, ryanodine converts from agonist to antagonist at concentrations $>10 \mu \mathrm{M}$ (Rousseau et al. 1987), but in intact cells, in which barriers to diffusion may exist, it has been shown to function as an agonist at concentrations as high as $50 \mu \mathrm{M}$ (Lilly and Gollan 1995).

Acetylcholine (ACh) is the principal neurotransmitter released by medial olivocochlear efferent axons (Eybalin 1993). Existing data suggest that an atypical nicotinic receptor (nAChR) composed of $\alpha 9$ and $\alpha 10$ subunits plays a central role at the synapse between efferent fibers and outer hair cells (Elgoyhen et al. 1994; 2001). These receptors pass an inward cation current followed within milliseconds by the activation of calcium-dependent potassium channels of the SK subtype (Blanchet et al. 1996; Evans 1996; Fuchs and Murrow 1992a; Glowatzki and Fuchs 2000; Nenov et al. 1996; Oliver et al. 2000). In addition, the postsynaptic hair cell is endowed with a synaptic cistern coextensive with the presynaptic efferent contacts (Saito 1983). The term "synaptoplasmic" cistern of the hair cell was coined to recognize an analogy to the sarcoplasmic reticulum of muscle (Lioudyno et al. 2004). It has recently been shown that calcium-activated potassium currents in rat outer hair cells evoked by ACh were altered by compounds that act on intracellular calcium stores, presumably the closely associated synaptoplasmic cistern. Calcium-induced calcium release by RyRs has been proposed as the most likely mechanism of store coupling in hair cells of the cochlea (Lioudyno et al. 2004). Thus, as in muscle, where tight coupling of voltage-gated calcium channels to ryanodine receptors in the sarcoplasmic reticulum mediates calcium-induced calcium release, nAChRs trigger a subsequent calcium-dependent process in hair cells. Although this general mechanism remains valid, the present study illustrates a surprising refinement resulting from the pharmacological promiscuity of the hair cell's AChR.

The $\alpha 9$ and $\alpha 10$ subunits that constitute the hair cell's AChR are distant members of the 'nicotinic' receptor family, and when expressed in Xenopus laevis oocytes, form a heteromeric receptor-channel complex that displays a pharmacological profile distinctly different from that of other cholinergic receptors, with sensitivity to glycinergic, gabaergic, serotonergic, as well as nicotinic and muscarinic antagonists (Elgoyhen et al. 1994, 2001). Moreover, nicotine and most nicotinic agonists, except for ACh, behave as antagonists, or very weak partial agonists, of this receptor subtype. Given that the $\alpha 9 \alpha 10$-containing hair cell cholinergic receptor is sensitive to a wide variety of chemically different compounds and that store coupling through calcium-induced calciumrelease in hair cells has been proposed on the basis of pharmacological approaches (Lioudyno et al. 2004), we examined the direct action of ryanodine on $\alpha 9 \alpha 10$ containing nAChRs. We report that ryanodine, in addition to acting on cytoplasmic calcium stores, is a positive modulator of the hair cell nAChR, the first such compound to be found. This opens the possibility for the design of related compounds that potentiate nAChR gating in cochlear hair cells (without also altering calcium store function) and therefore to increase potential benefits of medial efferent synaptic inhibition.

\section{MATERIALS AND METHODS}

\section{Expression of recombinant receptors in $X$. laevis oocytes}

Capped cRNAs were in vitro-transcribed from linearized rat plasmid DNA templates using the mMessage mMachine Transcription Kit (Ambion Corporation, Austin, TX). The maintenance of $X$. laevis, as well as the preparation and cRNA injection of stage $\mathrm{V}$ and VI oocytes, has been described in detail elsewhere (Katz et al. 2000). Typically, oocytes were injected with $50 \mathrm{nl}$ of RNase-free water containing 0.01-1.0 ng of cRNAs (at a 1:1 molar, and maintained in Barth's solution at $17^{\circ} \mathrm{C}$.

Electrophysiological recordings were performed 2-6 days after cRNA injection under two-electrode voltage-clamp with an OC-725B oocyte clamp (Warner Instruments, Hamden, CT). Both voltage and current electrodes were filled with $3 \mathrm{M} \mathrm{KCl}$ and had resistances of $\sim 1-2 \mathrm{M} \Omega$. Data were digitized and stored on a PC computer. Data were analyzed using Clampfit from the pClamp 6 software (Axon Instruments Corp., Union City, CA). During electrophysiological recordings, oocytes were continuously superfused $(\sim 10 \mathrm{ml} / \mathrm{min}$ ) with normal frog saline (comprised of, in $\mathrm{mM}$ : $115 \mathrm{NaCl}, 2.5 \mathrm{KCl}, 1.8 \mathrm{CaCl}_{2}$, and 10 HEPES buffer, $\mathrm{pH}$ 7.2) and voltage-clamped at $-70 \mathrm{mV}$. Experiments were performed in oocytes incubated with the $\mathrm{Ca}^{2+}$ chelator 1,2-bis (2-aminophenoxy)ethane- $N, N, N, N$-tetraacetic acid-acetoxymethyl ester (BAPTA-AM, $100 \mu \mathrm{M}$ ) for 3-4 h before electrophysiological recordings. Drugs were applied in the perfusion solution of the oocyte chamber.

Concentration-response curves were normalized to the maximal agonist response in the absence of ryanodine. Ryanodine was added to the perfusion solution for $2 \mathrm{~min}$ before the addition of ACh and then were coapplied with this agonist. Responses were referred to as a percentage of the response to ACh. The mean and standard error of the mean of 
peak current responses are represented. Agonist concentration-response curves were iteratively fitted with the equation:

$$
I / I_{\max }=A^{n} /\left(A^{n}+E C_{50}^{n}\right)
$$

where $I$ is the peak inward current evoked by the agonist at concentration $A ; I_{\max }$ is current evoked by the concentration of agonist eliciting a maximal response; $\mathrm{EC}_{50}$ is the concentration of agonist inducing half-maximal current response, and $n$ is the Hill coefficient.

\section{Recordings from mouse inner hair cells}

Apical turns of the organ of Corti were excised from CF1 mice at postnatal ages 8-10. Cochlear preparations were mounted under an Axioskope microscope (Zeiss, Oberkochen, Germany) and viewed with differential interference contrast (DIC) using a $40 \times$ water immersion objective and a camera with contrast enhancement (Hamamatsu C2400-07, Hamamatsu City, Japan). Methods to record from inner hair cells (IHCs) were essentially as described (Gomez-Casati et al. 2005). Briefly, IHC were identified visually by the size of their capacitance $(7-12 \mathrm{pF})$ and by their characteristic voltage-dependent $\mathrm{Na}^{+}$and $\mathrm{K}^{+}$currents, including at older ages, a fast-activating $\mathrm{K}^{+}$conductance. Some cells were removed to access IHCs, but mostly the pipette moved through the tissue using positive fluid flow to clear the tip. The extracellular solution was as follows (in $\mathrm{mM}$ ): 155 $\mathrm{NaCl}, 5.8 \mathrm{KCl}, 1.3 \mathrm{CaCl}_{2}, 0.9 \mathrm{MgCl}_{2}, 0.7 \mathrm{NaH}_{2} \mathrm{PO}_{4}$, 5.6 D-glucose, and 10 HEPES buffer; $\mathrm{pH}$ 7.4. The pipette solution was (in $\mathrm{mM}$ ): $150 \mathrm{KCl}, 3.5 \mathrm{MgCl}_{2}, 0.1$ $\mathrm{CaCl}_{2}, 10$ BAPTA, 5 HEPES buffer, $2.5 \mathrm{Na}_{2} \mathrm{ATP}, \mathrm{pH}$ 7.2. Glass pipettes (1.2 $\mathrm{mm}$ i.d.) had resistances of $7-$ $10 \mathrm{M} \Omega$. Solutions containing $60 \mu \mathrm{M}$ ACh (the $\mathrm{EC}_{50}$ in this preparation) and ryanodine were applied by a gravity-fed multichannel glass pipette $(\sim 150 \mu \mathrm{m}$ tip diameter) positioned about $300 \mu \mathrm{m}$ from the recorded IHC. The extracellular solution containing the drugs was similar to that described above, except that $\mathrm{Mg}^{2+}$ was omitted, and the $\mathrm{Ca}^{2+}$ concentration was lowered to $0.5 \mathrm{mM}$ to optimize the experimental conditions for measuring currents flowing through the $\alpha 9 \alpha 10$ receptors (Katz et al. 2004). To minimize even more the contribution of SK channel currents, in addition to using BAPTA in the pipette solution, the SK channel blocker apamin (1-10 nM) was added to the external working solutions. Currents in IHCs were recorded in the whole-cell patch-clamp mode using an Axopatch 200B amplifier, low-pass filtered at $2-10 \mathrm{kHz}$, and digitized at $5-20 \mathrm{kHz}$ with a Digidata 1200 board (Axon Instruments, Union City, CA). Recordings were made at room temperature (22- $25^{\circ} \mathrm{C}$ ). Voltages were not corrected for the voltage drop across the uncompensated series resistance.

\section{Whole-cell, gigohm-seal recording from isolated chicken hair cells}

Short (outer) hair cells were isolated by microdissection from the chicken cochlea (2-10 days posthatch) after cervical dislocation and decapitation. The cochlear duct was removed from the inner ear and treated with $0.1 \mathrm{mg} \mathrm{m}{ }^{-1}$ protease (Sigma Type XXIV) in low-divalent saline for 3-10 $\mathrm{min}$ at room temperature. The tegmentum vasculosum was cut away, exposing the basilar papilla. The tectorial membrane was pealed away with fine forceps, and a sharpened tungsten probe was used to cut several slits through the basilar papilla to loosen hair cells for eventual removal. A glass capillary (tip diameter about $50 \mu \mathrm{m}$ ) was used with mouth suction to vacuum hair cells from selected regions of the papilla. These were carefully plated onto a clean glass coverslip that served as the floor of the recording chamber. Short hair cells were collected from the abneural half of the epithelium between 1 and $2 \mathrm{~mm}$ from the apical (lagenar) end of the papilla. Because only small numbers of hair cells were collected at any one time, repeated isolates could be taken from one cochlea. Between isolations, the cochlear duct was either stored in a $37^{\circ} \mathrm{C}$, humidified incubator, or at room temperature under an 'oxygen tent' through which oxygen gas was passed continuously. Recordings were attempted from one set of isolated cells for 1-2 $\mathrm{h}$, and the cochlea was returned to for more cells over a period of 3-4 h.

Isolated hair cells were placed in a recording chamber on the stage of a Nikon Diaphot inverted microscope. Patch pipettes of 3-5 M $\Omega$ were pulled from borosilicate hematocrit glass (\#2-00-100, Drummond Scientific, Broomall, PA) and coated with purple ski-wax to reduce capacitance. Seals of 2-20 G $\Omega$ were made to the cell surface, then the whole-cell configuration was obtained by further brief pulses of suction. ACh $(100 \mu \mathrm{M})$ was applied from a 'puffer' pipette-another patch pipette filled with $100 \mu \mathrm{M}$ ACh in external saline, mounted on manipulator, and connected to a Picospritzer (General Valve Corp., Fairfield, NJ) for controlled pressure ejection. In most cases, a 100-ms puff of ACh was employed. Membrane currents were recorded under a voltage clamp (Axopatch 1D, Axon Instruments, Union City, $\mathrm{CA})$, filtered at 5 or $10 \mathrm{kHz}$, and digitized at $100-\mu \mathrm{s}$ intervals. Membrane potentials are reported here without correction for the junction potential of $-4 \mathrm{mV}$. Bath solutions were exchanged by gravity feed and suction drain. The standard external saline contained $(\mathrm{mM}): \mathrm{NaCl}, 150 ; \mathrm{KCl}, 5 ; \mathrm{MgCl}_{2}, 2$; 
$\mathrm{CaCl}_{2}, 5.6$; HEPES, 5; glucose, 8, adjusted to $\mathrm{pH} 7.4$ with $\mathrm{NaOH}$. The osmolarity was adjusted to $315 \mathrm{mOsm}$ with the predominant salt. The recording pipette contained (mM): $112 \mathrm{KCl}, 2 \mathrm{MgCl}_{2}, 0.1 \mathrm{CaCl}_{2}, 30$ $\mathrm{KOH}, 10$ EGTA, 10 HEPES and $5 \mathrm{Na}_{2} \mathrm{ATP}$ (titrated to pH 7.2 with $\mathrm{KOH}$; osmolarity adjusted to $295 \mathrm{mOsm}$ ). In some recordings, BAPTA was exchanged for EGTA. Ryanodine and other drugs were diluted from stock solutions and perfused through the recording chamber. Total bath volume was less than $0.5 \mathrm{ml}$ and replacement occurred within 15 s. However, several bath volumes of a new solution were exchanged before recordings were made. All experiments were conducted at room temperature $\left(22-24^{\circ} \mathrm{C}\right)$.

\section{Whole-cell, gigohm-seal recording from isolated outer hair cells}

The apical and upper middle turns were dissected from the otic capsule of 12- to 17-day-old rat pups. The excised turns were treated briefly with protease ( $5 \mathrm{~min}$ in $0.1 \mathrm{mg} / \mathrm{ml}$ of papain at room temperature); then, the organ of Corti was dissociated by aspiration into a small diameter pipette. The individually isolated cells were dispersed onto the clean glass floor of a recording chamber secured to the stage of an inverted microscope (Nikon Diaphot). Whole-cell, gigohm-seal recording conditions and solutions were the same as those used for the chicken hair cell experiments described above.

\section{Statistical analysis}

The statistical significance of differences between mean values was assessed by Student's $t$ test (twotailed, unpaired samples). Values of $p<0.05$ were considered significant. Unless otherwise stated, data is expressed as the mean \pm SEM.

Materials. ACh chloride or iodide was bought from Sigma-Aldrich Chemical Co. (St. Louis, MO). Ryanodine was obtained from various vendors including SigmaAldrich, LaToxan (Valence, France), and Tocris (Bristol, UK).

All experimental protocols were carried out in accordance with the Animal Care and Use Committee of Johns Hopkins University and with the National Institute of Health guide for the care and use of Laboratory animals (NIH Publications no. 80-23) revised 1978.

\section{RESULTS}

Ryanodine potentiates ACh-evoked responses in $\alpha 9 \alpha 10$-expressing Xenopus oocytes

To analyze the effect of ryanodine on $\alpha 9 \alpha 10$ receptors, we examined its action on agonist-evoked currents in Xenopus oocytes expressing the rat recombinant receptors. A concentration of $10 \mu \mathrm{M}$ ACh was initially used as it is near the $\mathrm{EC}_{50}$ for the agonist in this preparation (Elgoyhen et al. 2001). Shown in Figure 1 are representative current traces at increasing concentrations of ryanodine coapplied with ACh compared to controls before and after ryanodine. Ryanodine at concentrations greater than $100 \mu \mathrm{M}$ produced a significant potentiation of the response to $\mathrm{ACh}$. In the presence of $100 \mu \mathrm{M}$ ryanodine the response to ACh was $95-165 \%$ that of the control, with a mean of $122.76 \pm 8.07 \%$ ( $n=9)$; in $200 \mu \mathrm{M}, 104-$ $1,344 \%$, mean $417.7 \pm 192.9 \% \quad(n=8, p<0.046)$ and $103-1279 \%$, mean $503.37 \pm 388.06(n=3)$ in $300 \mu \mathrm{M}$ ryanodine (Fig. 2A). Preincubation with ryanodine gave similar results as did coapplication. In addition, ryanodine itself did not elicit membrane currents in the absence of ACh, arguing against a direct effect of ryanodine on oocytes' intracellular $\mathrm{Ca}^{2+}$ stores and subsequent alteration in the activation of the $\mathrm{Ca}^{2+}$ dependent $\mathrm{Cl}^{-}$current present in these cells (Boton et al. 1989).

To further characterize the effects and mechanism of action of $200 \mu \mathrm{M}$ ryanodine, we examined its action on ACh concentration-response curves. As seen in Figure 2B, ryanodine produced a left-ward shift of the dose-response curve, with a concomitant decrease in the $\mathrm{EC}_{50}$ for $\mathrm{ACh}$ from $15.4 \pm 1.63 \mu \mathrm{M}$ to $6.7 \pm 3.08 \mu \mathrm{M}(n=3-7$ for each data point; $p<0.05)$ but with no change in the Hill coefficient. Moreover, incubation with ryanodine resulted in an increase in the agonist-evoked currents, even at concentrations of agonist that evoked maximal responses in control conditions $(136.4 \pm 12.55 \%$ of the control response, $n=3-7$ for each data point).

Ryanodine potentiates ACh-evoked responses in native $\alpha 9 \alpha 10$-containing mouse hair cell receptors

The experiments in oocytes provide a clear demonstration that ryanodine potentiates responses of $\alpha 9 \alpha 10$ receptors. This is the first of such compounds to be found and opens the possibility of designing new molecules that modulate synaptic responses mediated through $\alpha 9 \alpha 10 \mathrm{nAChRs}$ in vivo. Mature outer and neonatal inner cochlear hair cells are the main targets of descending cholinergic olivocochlear efferent fibers (Guinan 1996). ACh released from efferent endings activates $\alpha 9 \alpha 10 \mathrm{nAChRs}$ in hair cells (Elgoyhen et al. 1994, 2001; Gomez-Casati et al. 2005; Lustig et al. 2001; Sgard et al. 2002). Thus, recordings from inner hair cells of the neonatal mouse cochlea were used to evaluate the effects of ryanodine on native $\alpha 9 \alpha 10$ nAChRs. As shown in Figure 3, 

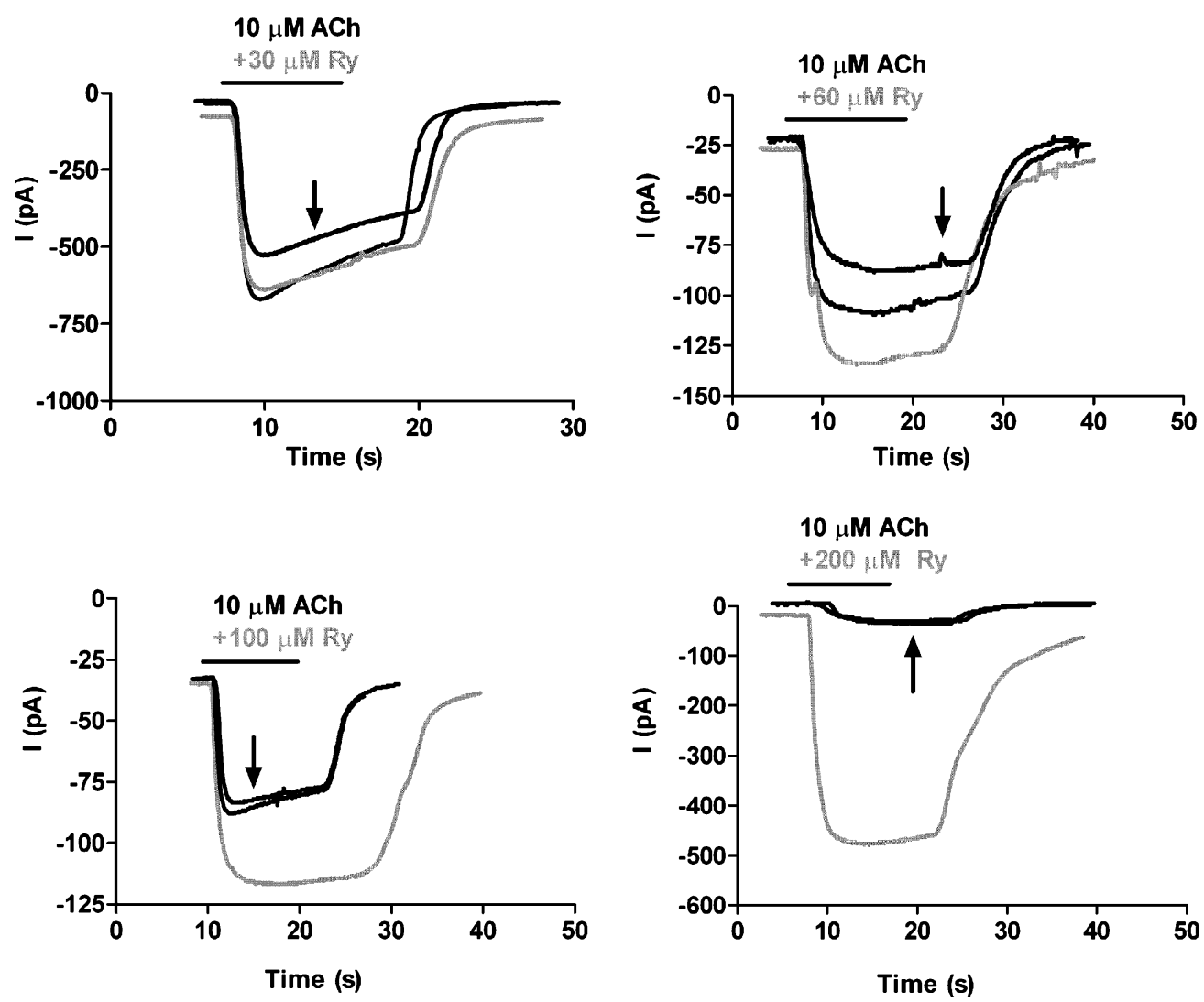

FIG. 1. Effect of ryanodine on ACh-evoked currents in oocytes expressing the $\alpha 9 \alpha 10$ nAChR. Representative traces of currents evoked by 10 $\mu \mathrm{M} \mathrm{ACh}, V_{\text {hold }}=-70 \mathrm{mV}$, in the absence (black traces) and presence (gray traces) of different concentrations of ryanodine. The effect of ryanodine on the amplitude of ACh-evoked currents was reversible (arrows indicate the postryanodine control response).

$200 \mu \mathrm{M}$ of ryanodine potentiated responses $(264.4 \pm$ $51 \%$ of the control, $n=8$ ) to $60 \mu \mathrm{M}$ ACh (the $\mathrm{EC}_{50}$ of the agonist in this preparation; Gomez-Casati et al. 2005), thus demonstrating a modulatory effect of ryanodine on native $\alpha 9 \alpha 10$-containing receptors. These recordings were performed with cytoplasmic calcium buffered by BAPTA, plus $10 \mathrm{nM}$ apamin in the external saline, to prevent activation of the associated SK current (Gomez-Casati et al. 2005), confirming that ryanodine was acting directly on the hair cell's AChRs.

Effect of ryanodine on the cholinergic response of chicken hair cells

This effect of ryanodine was not unique to mammalian hair cells. Short hair cells are the avian counterpart of mammalian outer hair cells (OHCs). Like OHCs, short hair cells are contacted by efferent fibers that release ACh to elicit a biphasic membrane current (Fuchs and Murrow 1992b). Calcium influx through a 'nicotinic' AChR is followed by the activation of calcium-dependent SK channels (Fuchs and Murrow 1992b; McNiven et al. 1996). As in the foregoing experiments in the rat cochlea, current through the chicken short hair cell AChR alone can be studied when cytoplasmic calcium is buffered with BAPTA $(10 \mathrm{mM})$. As shown in Figure 4, inward currents at $-70 \mathrm{mV}$, elicited by brief $(100 \mathrm{~ms})$ application of $100 \mu \mathrm{M} \mathrm{ACh}$, were potentiated by $100 \mu \mathrm{M}$ ryanodine (peak inward currents in control averaged $-10.1 \mathrm{pA}, \pm 1.6, n=13$; after exposure to ryanodine, $-45.3 \mathrm{pA} \pm 6.3, n=13, p<0.01)$. In addition to the marked increase in peak current, the time to peak increased $\sim$ threefold (from $20 \mathrm{~ms} \pm 3.5$ to $75 \mathrm{~ms} \pm 25, p<0.05)$. However, half-decay time was not changed significantly (control: $922 \mathrm{~ms} \pm 183$, vs ryanodine: 1,092 ms \pm 150 ), Figure 4B. ACh receptors in chicken hair cells, like in mammals, are most sensitive to block by strychnine (Fuchs and Murrow 1992b). The ryanodine-potentiated inward currents were blocked completely and reversibly by $1 \mu \mathrm{M}$ strychnine (Fig. 4C), further supporting the notion that the potentiating effect was specific to the hair cell AChR. Consistent with this point, the reversal potential for the ryanodine-enhanced inward current, $+4 \mathrm{mV}$, was unchanged from that of the control inward current (McNiven et al. 1996). Finally, the potentiating effects of ryanodine were completely reversible. 

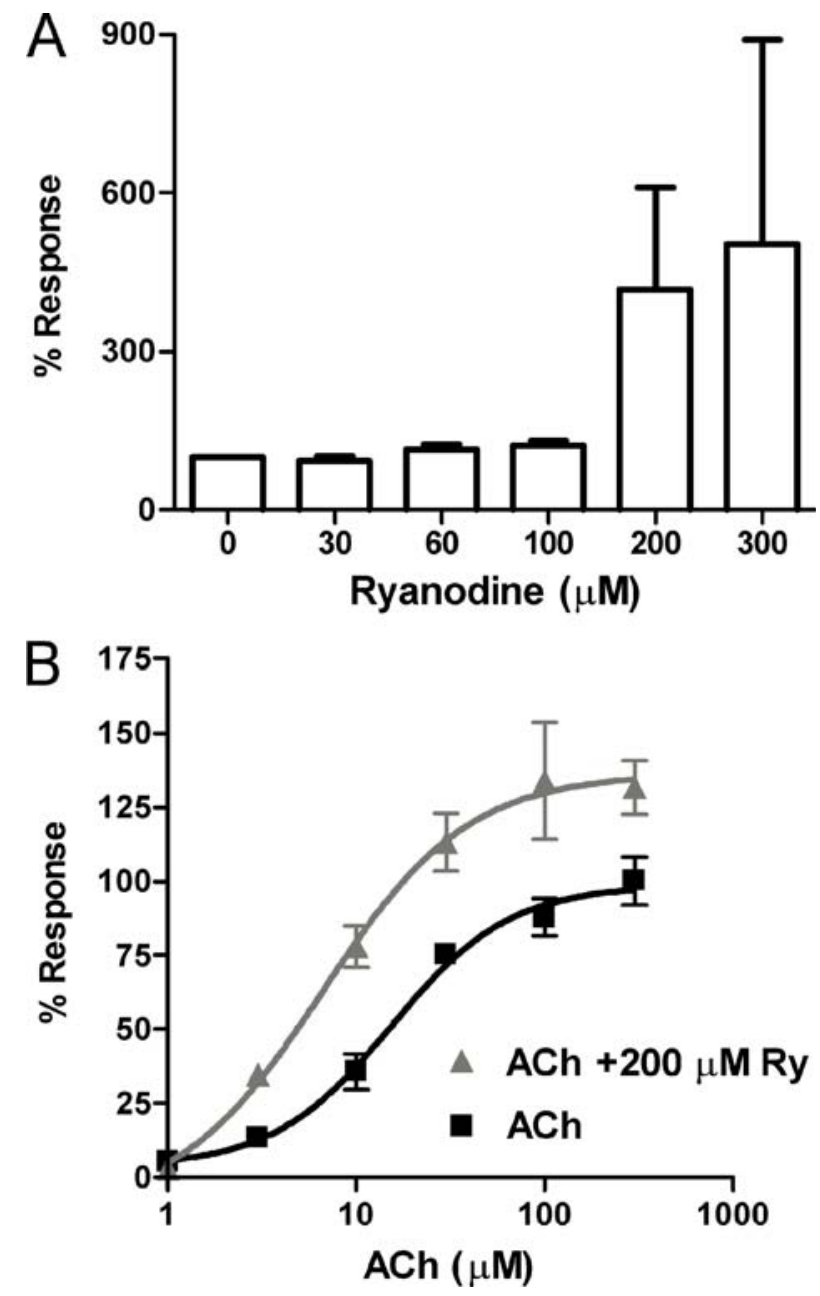

FIG. 2. Ryanodine increases the sensitivity of the $\alpha 9 \alpha 10 \mathrm{nAChR}$ for ACh. A Mean and standard error of the percent change in response to $10 \mu \mathrm{M} \mathrm{ACh}$ (at $-70 \mathrm{mV}$, internal BAPTA buffering) for different concentrations of ryanodine $(30,60,100$, and $200 \mu \mathrm{M}, n=3-9$ per concentration). B Concentration-response curves to $\mathrm{ACh}$ in the absence and presence of $200 \mu \mathrm{M}$ ryanodine $(n=3-7$ per concentration). Ryanodine increased the apparent affinity of the recombinant $\alpha 9 \alpha 10 \mathrm{nAChR}$ for $\mathrm{ACh}$ and also the amplitude of responses to saturating concentrations of this agonist. $V_{\text {hold }}=-70 \mathrm{mV}$.

The effect of ryanodine on the ACh-evoked SK current

The effect of ryanodine on the hair cell's cholinergic response also could be studied under conditions (cytoplasmic calcium buffering with EGTA) that preserved the associated calcium-dependent SK current (Fuchs and Murrow 1992b). The outward SK current at $-40 \mathrm{mV}$ evoked by ACh was made longer-lasting, but not larger, by exposure to $100 \mu \mathrm{M}$ ryanodine (Fig. 5A). The duration at half-amplitude nearly doubled (control duration at half amplitude: $435.4 \mathrm{~ms} \pm 60.3, n=18$; in ryanodine: $772.3 \mathrm{~ms} \pm 102.1, n=18, p=0.008$ ); whereas peak amplitude was unchanged (control peak 425 $\mathrm{pA} \pm 81, n=18$; ryanodine peak $383 \mathrm{pA} \pm 79, n=18)$. This
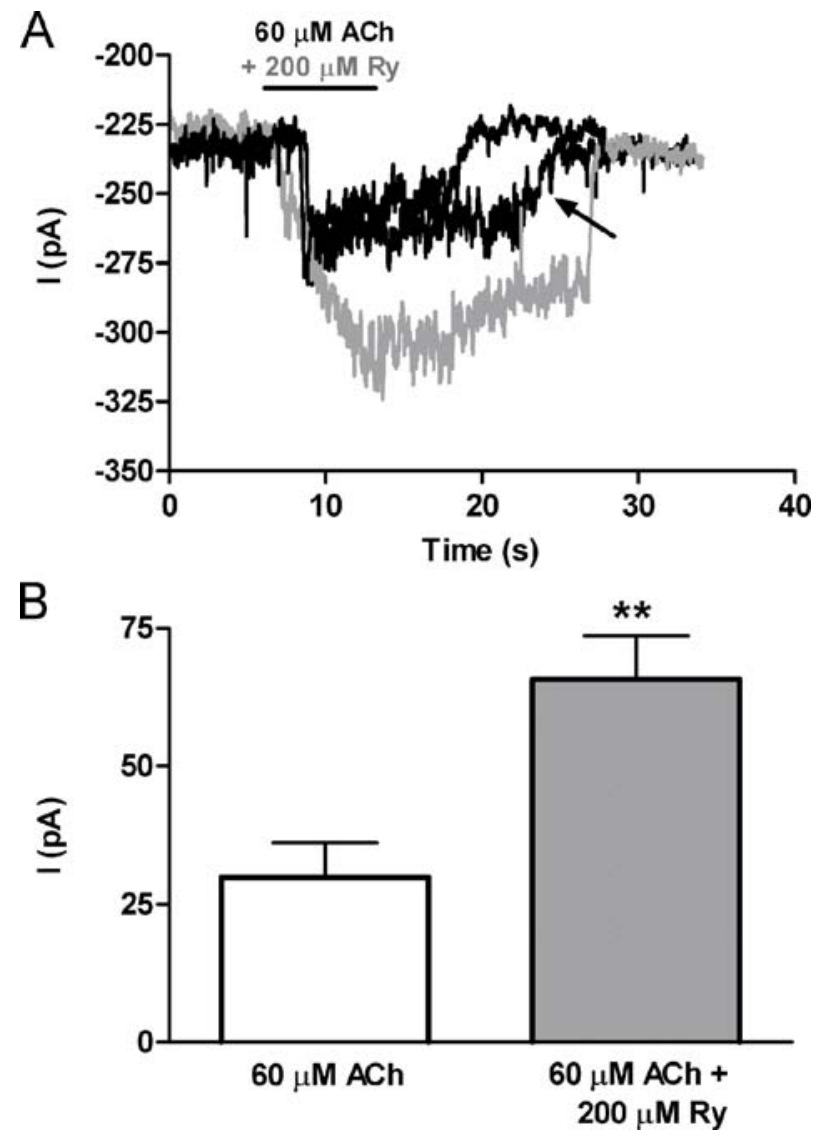

FIG. 3. The activity of the native cochlear $\alpha 9 \alpha 10 \mathrm{nAChR}$ in mouse IHCs is potentiated by ryanodine. A Representative traces of currents evoked by $60 \mu \mathrm{M}$ ACh in mouse IHCs $\left(V_{\text {hold }}=-90 \mathrm{mV}\right)$ in the absence (black trace) and presence of $200 \mu \mathrm{M}$ ryanodine (gray trace). The patch pipette contained $10 \mathrm{mM}$ BAPTA and the extracellular solution $10 \mathrm{nM}$ apamin so as to record currents through the native $\alpha 9 \alpha 10$ $\mathrm{nAChR}$ in isolation from the SK2 channel. B Bar diagram summarizing the effects of ryanodine $200 \mu \mathrm{M}$ on the response to ACh in eight IHCs.

increase in SK current duration was readily reversed upon washing out ryanodine.

A similar result was obtained in a smaller number of OHCs dissociated from the apical turn of postnatal rats (P12-17). A $100-\mathrm{ms}$ puff of $100 \mu \mathrm{M}$ ACh produced outward currents at -40 to $-50 \mathrm{mV}$ membrane potential. These were smaller and longer-lasting, with irregular decay phases compared to those usually seen in isolated chicken hair cells (Fig. 5B). Nonetheless, exposure to $100 \mu \mathrm{M}$ ryanodine lengthened the duration of the ACh response still further, nearly doubling the duration at half-amplitude (control 339 ms \pm 54 ; ryanodine $516 \mathrm{~ms} \pm 46, n=4, p=0.03)$. In addition, as in the chicken hair cells, the peak AChevoked current was not significantly changed by ryanodine (control, $44 \mathrm{pA} \pm 18$; ryanodine, $53 \mathrm{pA} \pm$ 27). The effects of ryanodine on ACh-evoked SK currents in both chicken and rat hair cells support the conclusion that exposure to ryanodine enhances 

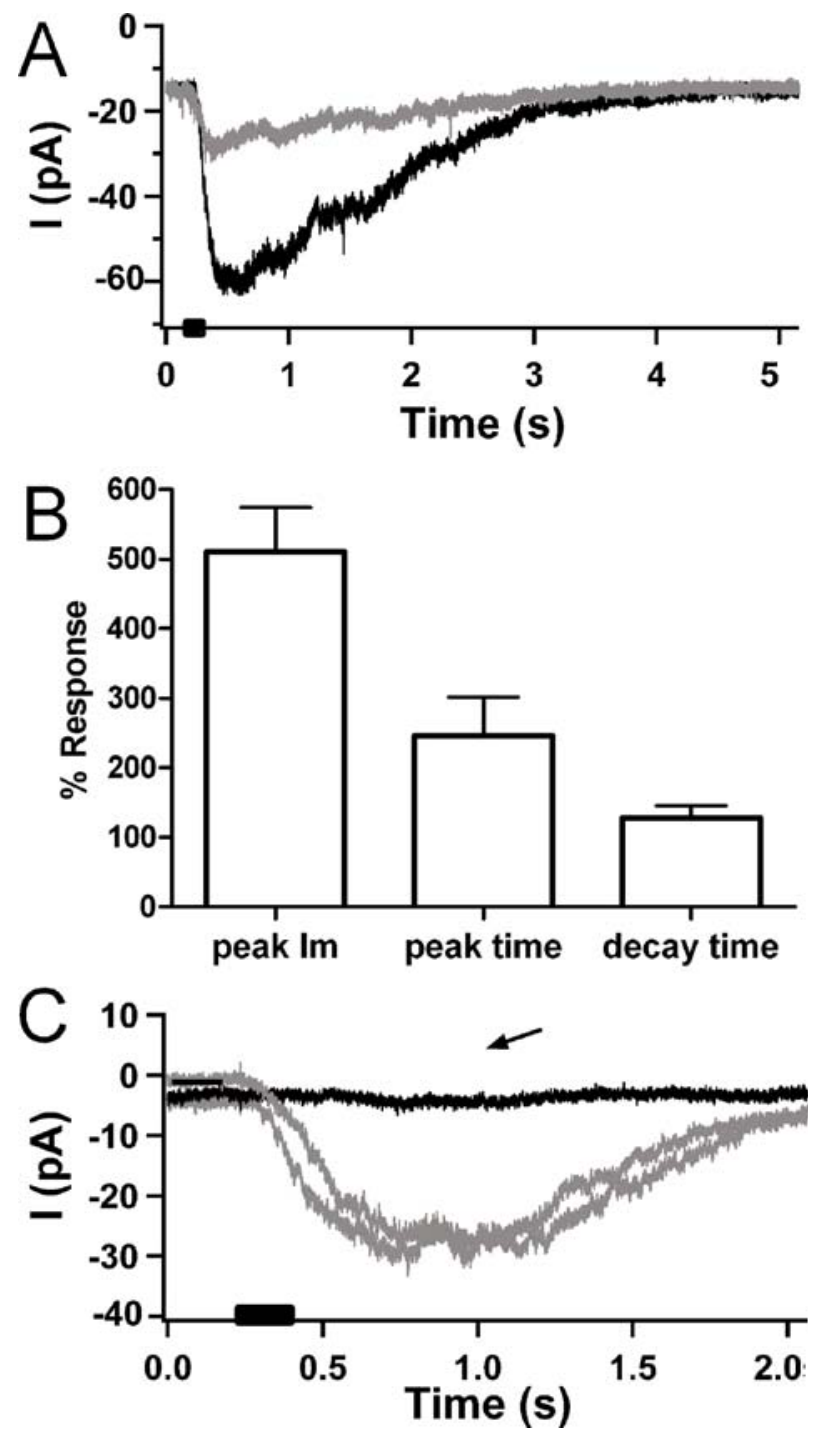

FIG. 4. Effects of ryanodine on the cholinergic response of chicken hair cells. A Inward current at $-70 \mathrm{mV}$ in a chicken hair cell buffered internally with $10 \mathrm{mM}$ BAPTA to eliminate calcium-dependent SK current. Application of $100 \mu \mathrm{M}$ ACh for $100 \mathrm{~ms}$ (puffer timing indicated by black bar on $\mathrm{x}$-axis) gave rise to a small inward current under control conditions $(\sim 15 \mathrm{pA})$. After exposure to $100 \mu \mathrm{M}$ ryanodine, the same 'puff' of ACh produced a fourfold larger inward current (gray). B The average percent change produced by $100 \mu \mathrm{M}$ ryanodine in membrane current evoked by ACh ( $n=13)$. Peak inward current increased $\sim$ fivefold, time to peak increased two- to threefold, but decay time was essentially unchanged. C Inward current evoked by ACh in chicken short hair cells (puffer timing indicated by black bar on $\mathrm{x}$-axis) and enhanced by $100 \mu \mathrm{M}$ ryanodine was blocked reversibly (gray traces before and after strychnine) by exposure to $1 \mu \mathrm{M}$ strychnine (black trace), $n=2$.

calcium influx through the hair cell's AChR, as the activation of associated calcium-activated SK channels is prolonged. This is opposite to the expectation based on ryanodine's inhibition of calcium release from internal stores. At least over the time scale of these responses then, the positive modulation of AChR gating outweighs any other effects ryanodine might have on calcium store function.
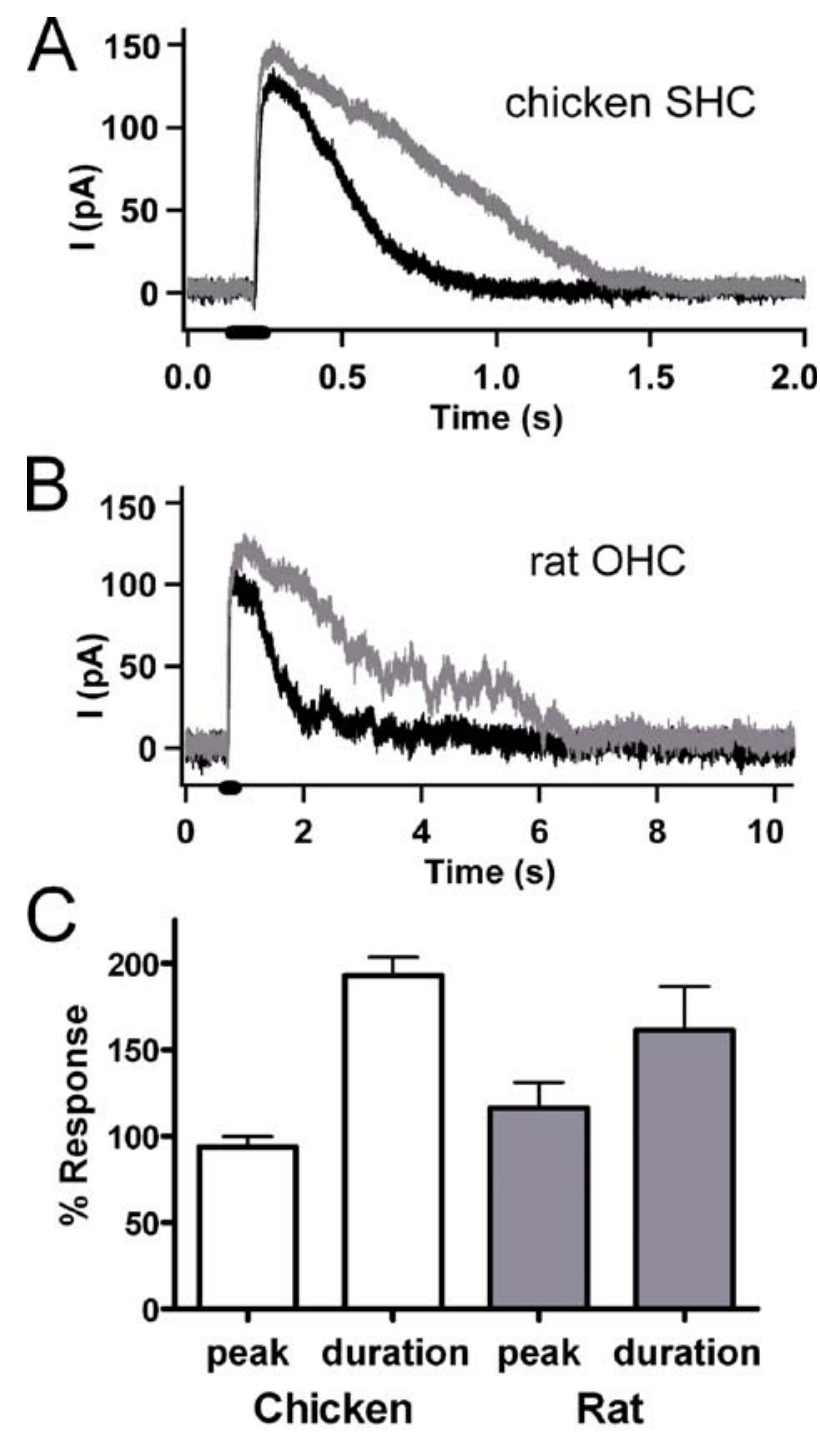

FIG. 5. Effect of ryanodine on ACh-evoked SK currents in chicken and rat hair cells. A Outward currents through SK channels in isolated chicken short hair cells (at $-40 \mathrm{mV}, 10 \mathrm{mM}$ EGTA internal buffer), evoked by $100 \mu \mathrm{M}$ ACh (100 ms puff at black bar on x-axis), were increased (reversibly) in duration by exposure to $100 \mu \mathrm{M}$ ryanodine (gray trace). B Puff application of ACh $(100 \mathrm{~ms}, 100 \mu \mathrm{M}$, at black bar on $\mathrm{x}$-axis) produced outward current at $-50 \mathrm{mV}$ (black trace) in a rat (P16) OHC (10 mM EGTA internal buffer). Exposure to $100 \mu \mathrm{M}$ ryanodine lengthened the response (gray trace). This effect could be reversed. C Ratio of experimental to control amplitude and duration of SK current (as in A, B) following exposure to $100 \mu \mathrm{M}$ ryanodine. In both chicken short $(n=18)$ and rat outer $(n=4)$ hair cells, the half-amplitude duration of the outward SK current evoked by ACh doubled in ryanodine, while peak amplitude was not changed significantly.

\section{DISCUSSION}

Cholinergic inhibition of the cochlea is mediated by an unusual member of the nicotinic receptor family of ligand-gated ion channels composed of $\alpha 9$ and $\alpha 10$ subunits (Elgoyhen et al. 1994, 2001). Not only do these nonselective cation channels paradoxically cause 
inhibition through associated calcium-dependent SK channels, but their pharmacology is unique, being antagonized rather than activated by nicotine and blocked by submicromolar concentrations of compounds such as strychnine and bicuculline (Elgoyhen et al. 2001; Rothlin et al. 1999). Indeed, with the exception of carbachol and acetylcholine itself, essentially none of the usual nicotinic agonists are effective, leaving the impression of a receptor subtype with broad antagonist sensitivity but one with a highly selective agonist binding site. Thus, in the absence of a wide variety of agonists, the identification of positive allosteric modulators of $\alpha 9 \alpha 10$ receptors is an alternative way to reinforce endogenous cholinergic neurotransmission. The ability to modulate the function of hair cell AChRs offers a potentially powerful method for treating conditions such as hyperacusis or even as prophylaxis for unavoidable loud sound exposure. By altering the response of an ionotropic receptor to endogenous agonists, the modulator can change the level of signaling. One of the most successful examples of therapeutic intervention based on this strategy is the use of benzodiazepines to enhance the response of $\mathrm{GABA}_{\mathrm{A}}$ receptors and augment inhibitory activity in the central nervous system (Macdonald and Olsen 1994).

Like other ligand-gated ion channels, the $\alpha 9 \alpha 10$ nAChR is both activated and desensitized by agonists in a concentration-dependent manner (Elgoyhen et al. 2001). Thus, continuous exposure to an agonist may impose a relatively narrow 'effective-concentration' range in which the receptors are activated but not fully desensitized (Hogg and Bertrand 2004). For example, in the case of $\alpha 7$ nAChRs, receptor desensitization may contribute to the relatively modest effect of nicotine on specific neurocognitive measures in human clinical studies (Harris et al. 2004; Smith et al. 2002). Unlike agonists, positive allosteric modulators do not directly activate or desensitize ligand-gated receptors; instead, they enhance the sensitivity and/or efficacy of the receptor during agonist activation. The positive modulatory effects of ryanodine reported here were especially surprising and are the first to be described for $\alpha 9 \alpha 10$ nAChRs, encouraging further exploration of this molecular pharmacology. This interaction may provide general instruction toward a pharmacological design for allosteric modulators that are effective at the synapse between olivocochlear fibers and hair cells of the inner ear.

Ryanodine increased both the potency, as well as the maximal response of $\alpha 9 \alpha 10$ nAChRs for ACh in Xenopus laevis oocytes. Moreover, potentiation was also observed in native $\alpha 9 \alpha 10$-containing receptors. The fact that potentiation occurred within seconds and was reversible suggests that incorporation of receptors, whether newly synthesized or drawn from intracellular stores, seems an unlikely explanation. As has been proposed for the potentiating effect of certain compounds on other nAChRs (Conroy et al. 2003; Curtis et al. 2002; Hurst et al. 2005; Krause et al. 1998; Zwart et al. 2002), the most likely interpretation of the present results is that ryanodine acts as a positive allosteric effector, recognizing a specific binding site within the receptor protein. Another formal possibility is that ryanodine is having its effect through 'conformational coupling' between hair cell AChRs and ryanodine receptors (RyR) as occurs during calcium release from sarcoplasmic reticulum in skeletal muscle. The close $(20-30 \mathrm{~nm})$ apposition of plasma and cisternal membranes in hair cells approximates that at triadic junctions in muscle. Of course, for this explanation to hold, $\alpha 9 \alpha 10$ also would have to interact with native RyRs in Xenopus oocytes, and these seem to be absent in these cells (Parys et al 1992). Whatever the eventual resolution of binding mechanism, it will be of interest to determine whether the effect of ryanodine includes an alteration of channel gating per se, as suggested by the increased maximal response and altered activation of hair cell responses to ACh.

\section{Comparisons to earlier work}

The results presented here are opposite in effect to the known inhibition by ryanodine of calcium release in muscle and other cell types (Buck et al. 1992; Sutko et al. 1997). More significantly, these are at odds with earlier work showing that ryanodine inhibits cholinergic action on outer hair cells of the rat cochlea (Lioudyno et al. 2004). In the present study, high concentrations of ryanodine $(100 \mu \mathrm{M})$ prolonged the SK current generated in rat OHCs by a brief application of ACh (Fig. 5). The earlier study showed that $100 \mu \mathrm{M}$ of ryanodine reduced the amplitude of ACh-evoked currents in rat OHCs in the ex vivo organ of Corti preparation and left the time course of synaptic waveforms unchanged. A partial reconciliation of the earlier results and the present data can be obtained by recognizing that ryanodine also can act to alter the contribution of internal stores to the ACh-evoked, calcium-dependent $\mathrm{K}^{+}$currents. In the earlier work, a weaker cytoplasmic buffer (5 vs $10 \mathrm{mM}$ EGTA) may have allowed ryanodine's inhibition of better-loaded calcium stores to predominate (Lioudyno et al. 2004). Given the complexity of ryanodine's effects, a given outcome will depend on experimental conditions. The enhanced activation of hair cell AChRs shown here may explain in part the enhancement of efferent inhibition produced by ryanodine in the guinea pig cochlea (Sridhar et al. 1997). 
Consideration of these studies makes clear that intracellular calcium stores, especially near-membrane synaptic cisterns like those in hair cells, make challenging subjects for investigation. The contributions of such stores will depend on their state of loading, the efficacy of buffering and pumping, and the time course of stimulation. Furthermore, pharmacological agents aimed at store function can have multiphasic effects, depending on timing. For example, the ryanodine receptor agonist caffeine first enhanced and then suppressed ACh-evoked SK currents in rat OHCs (Lioudyno et al. 2004). These complexities are exacerbated by the relative nonselectivity of most such store-active compounds. The present study takes this one step further by showing that ryanodine, a quintessential tool for studying calcium stores, has still further sites of action. In summary, this work demonstrates a novel, positive modulation of the hair cell's $\alpha 9 \alpha 10$-containing AChR by the store-active agent ryanodine. These data provide new insights into the characteristics of this unusual nicotinic receptor and advance our understanding of the molecular mechanisms of cochlear inhibition.

\section{ACKNOWLEDGMENTS}

This work was supported by an International Research Scholar Grant from the Howard Hughes Medical Institute and a Research Grant from ANPCyT (Argentina) to A.B.E., a Research grant from Universidad de Buenos Aires (Argentina) to A.B.E. and E.K., a Research Grant from CONICET (Argentina) to E.K., and the National Institutes of Deafness and other Communication Disorders (NIDCD) Grant R01DC001508 to P.A.F. and A.B.E.

\section{REFERENCES}

Blanchet C, Erostegui C, Sugasawa M, Dulon D. Acetylcholineinduced potassium current of guinea pig outer hair cells: its dependence on a calcium influx through nicotinic-like receptors. J. Neurosci. 16:2574-2584, 1996.

Boton R, Dascal N, Gillo B, Lass Y. Two calcium-activated chloride conductances in Xenopus laevis oocytes permeabilized with the ionophore A23187. J. Physiol. 408:511-534, 1989.

Buck E, Zimanyi I, Abramson JJ, Pessah IN. Ryanodine stabilizes multiple conformational states of the skeletal muscle calcium release channel. J. Biol. Chem. 267:23560-23567, 1992.

Conroy WG, Liu QS, Nai Q, Margiotta JF, Berg DK. Potentiation of alpha7-containing nicotinic acetylcholine receptors by select albumins. Mol. Pharmacol. 63:419-428, 2003.

Coronado R, Morrissette J, Sukhareva M, Vaughan DM. Structure and function of ryanodine receptors. Am. J. Physiol. 266:C1485C1504, 1994.

Curtis L, Buisson B, Bertrand S, Bertrand D. Potentiation of human alpha4beta2 neuronal nicotinic acetylcholine receptor by estradiol. Mol. Pharmacol. 61:127-135, 2002.

Elgoyhen AB, Johnson DS, Boulter J, Vetter DE, Heinemann S. $\alpha 9$ : an acetylcholine receptor with novel pharmacological properties expressed in rat cochlear hair cells. Cell. 79:705$715,1994$.

Elgoyhen AB, Vetter D, Katz E, Rothlin C, Heinemann S, Boulter J. Alpha 10: A determinant of nicotinic cholinergic receptor function in mammalian vestibular and cochlear mechanosensory hair cells. Proc. Nat. Acad. Sci. U. S. A. 98:3501-3506, 2001.

Evans M. Acetylcholine activates two currents in guinea-pig outer hair cells. J. Physiol. 491:563-578, 1996.

Eybalin M. Neurotransmitters and neuromodulators of the mammalian cochlea. Physiol. Rev. 73:309-373, 1993.

Fuchs PA, Murrow BW. Cholinergic inhibition of short (outer) hair cells of the chick's cochlea. J. Neurosci. 12:800-809, 1992a.

Fuchs PA, MurRow BW. A novel cholinergic receptor mediates inhibition of chick cochlear hair cells. Proc. R. Soc. Lond. B. 248:35-40, 1992b.

Glowatzki E, Fuchs P. Cholinergic synaptic inhibition of inner hair cells in the neonatal mammalian cochlea. Science. 288:23662368, 2000.

Gomez-Casati ME, Fuchs PA, Elgoyhen AB, Katz E. Biophysical and pharmacological characterization of nicotinic cholinergic receptors in cochlear inner hair cells. J. Physiol. 566:103-118, 2005.

Guinan JJ. Physiology of olivocochlear efferents. In: Dallos P, Popper AN, and Fay RR (eds) The Cochlea. New York, Springer, pp 435-502, 1996.

Harris JG, Kongs S, Allensworth D, Martin L, Tregellas J, Sullivan B, Zerbe G, Freedman R. Effects of nicotine on cognitive deficits in schizophrenia. Neuropsychopharmacol. 29:1378-1385, 2004.

Hogg RC, Bertrand D. Nicotinic acetylcholine receptors as drug targets. Curr. Drug. Targets CNS Neurol. Disord. 3:123-130, 2004.

Hurst RS, Hajos M, Raggenbass M, Wall TM, Higdon NR, Lawson JA, Rutherford-Root KL, Berkenpas MB, Hoffmann WE, Piotrowski DW, Groppi VE, Allaman G, Ogier R, Bertrand S, Bertrand D, Arneric SP. A novel positive allosteric modulator of the alpha7 neuronal nicotinic acetylcholine receptor: in vitro and in vivo characterization. J. Neurosci. 25:4396-4405, 2005.

Katz E, Verbitsky M, Rothlin C, Vetter D, Heinemann S, Elgoyhen A. High calcium permeability and calcium block of the $\alpha 9$ nicotinic acetylcholine receptor. Hearing Res. 141:117-128, 2000.

Katz E, Elgoyhen AB, Gomez-Casati ME, Knipper M, Vetter DE, Fuchs PA, GLowatzki E. Developmental regulation of nicotinic synapses on cochlear inner hair cells. J. Neurosci. 24:78147820, 2004.

Krause RM, Buisson B, Bertrand S, Corringer PJ, Galzi JL, Changeux JP, Bertrand D. Ivermectin: a positive allosteric effector of the alpha7 neuronal nicotinic acetylcholine receptor. Mol. Pharmacol. 53:283-294, 1998.

Lilly LB, Gollan JL. Ryanodine-induced calcium release from hepatic microsomes and permeabilized hepatocytes. Am. J. Physiol. 268:G1017-G1024, 1995.

Lioudyno M, Hiel H, Kong JH, Katz E, Waldman E, ParameshwaranIyer S, Glowatzki E, Fuchs PA. A "synaptoplasmic cistern" mediates rapid inhibition of cochlear hair cells. J. Neurosci. 24:11160-11164, 2004.

Lustig LR, Peng H, Hiel H, Yамamoto T, Fuchs P. Molecular cloning and mapping of the human nicotinic acetylcholine receptor a10 (CHRNA10). Genomics. 73:272-283, 2001.

Macdonald RL, Olsen RW. GABAA receptor channels. Annu. Rev. Neurosci. 17:569-602, 1994.

McNiven AI, Yuhas WA, Fuchs PA. Ionic dependence and agonist preference of an acetylcholine receptor in hair cells. Auditory Neurosci. 2:63-77, 1996.

Nenov AP, Norris C, BobBIn RP. Acetylcholine responses in guinea pig outer hair cells. II Activation of a small conductance Ca2+activated K+ channel. Hearing Res. 101:149-172, 1996.

Oliver D, Klocker N, Schuck J, Baukrowitz T, Ruppersberg JP, FAKLER B. Gating of Ca2+-activated K+ channels controls fast 
inhibitory synaptic transmission at auditory outer hair cells. Neuron. 26:595-601, 2000.

Parys JB, Sernett SW, Delisle S, Snyder PM, Welsh MJ, Campbell KP. Isolation, characterization, and localization of the inositol 1,4,5-trisphosphate receptor protein in Xenopus laevis oocytes. J. Biol. Chem. 267:18776-18782, 1992.

Rothlin C, Verbitsky M, Katz E, Elgoyhen A. The $\alpha 9$ nicotinic acetylcholine receptor shares pharmacological properties with type A g-aminobutyric acid, glycine and type 3 serotonin receptors. Molec. Pharmacol. 55:248-254, 1999.

Rousseau E, Smith JS, Meissner G. Ryanodine modifies conductance and gating behavior of single Ca2+ release channel. Am. J. Physiol. 253:C364-C368, 1987.

SAITO K. Fine structure of the sensory epithelium of guinea-pig organ of Corti: subsurface cisternae and lamellar bodies in the outer hair cells. Cell Tissue Res. 229:467-481, 1983.

Sgard F, Charpentier E, Bertrand S, Walker N, Caput D, Graham D, Bertrand D, Besnard F. A novel human nicotinic receptor subunit, $\alpha 10$, that confers functionality to the $\alpha 9$-subunit. Molec. Pharmacol. 61:150-159, 2002.

Smith RC, Singh A, Infante M, Khandat A, Kloos A. Effects of cigarette smoking and nicotine nasal spray on psychiatric symptoms and cognition in schizophrenia. Neuropsychopharmacol. 27:479-497, 2002.

Sridhar TS, Brown MC, Sewell WF. Unique postsynaptic signaling at the hair cell efferent synapse permits calcium to evoke changes on two time scales. J. Neurosci. 17:428-437, 1997.

Sutko JL, Airey JA, Welch W, Ruest L. The pharmacology of ryanodine and related compounds. Pharmacol. Rev. 49:53-98, 1997.

Zwart R, De Filippi G, Broad LM, McPhie Gi, Pearson KH, Baldwinson T, SHER E. 5-Hydroxyindole potentiates human alpha 7 nicotinic receptor-mediated responses and enhances acetylcholine-induced glutamate release in cerebellar slices. Neuropharmacol. 43:374-384, 2002. 